\title{
ENHANCING INDONESIAN VOCATIONAL HIGH SCHOOL GRADUATE'S COMPETENCE IN THE WORLD OF WORK AFTER COVID-19 PANDEMIC THROUGH INNOVATIVE LEARNING MODELS
}

\author{
ISMADA FIRDAUS MANDALA PUTRA*
}

\begin{abstract}
This research explores innovative learning models to ensure that Indonesian vocational high school graduates still have an excellent competency after being hit by the Covid-19 pandemic. This research adopted the qualitative method by conducting content analysis. Based on the analysis, this study has discovered three innovative learning methods, namely [1] researchbased learning; to enhance data literacy, [2] interactive multimedia-based learning; for increasing technological literacy, and [3] project-based learning; conducted to empower human literacy. The students' capabilities to compete in the corporate world are better if they apply these three learning models. It would also reduce the risk of unemployment due to technological disruption during the pandemic and the increased population by acquiring these literacy skills. It is hoped that vocational high school graduates will be hired fast and able to take part in the corporate world and have the three new literacy skills as the principal capital in taking part in the corporate world.
\end{abstract}

Keywords: Competence of vocational high school graduates; Covid-19 pandemic; Innovative learning models

\section{INTRODUCTION}

The quality of education should be improved in order to produce a bright generation in the midst of a digitalized society. All the benefits of the digital era, such as increasing effectiveness and time efficiency in activities, of course also go hand in hand with risks that can have a negative impact. The latest technology in the digital era can also replace the role of humans themselves, including in the world of work. Therefore, some types of jobs are predicted to be lost. When that happens, the next implication that will arise is mass unemployment where this problem can also trigger a decline in the level of a country's economy. In fact, improving the quality of education is the key to success in conquering various kinds of problems in the digital era, one of which is mass unemployment.

Digitization and the Covid-19 pandemic, both of them can cause job losses and lead to unemployment. As many as 800 million jobs worldwide are in danger of being wiped out because they are replaced by the performance of the latest technology in the digital age such as cloud computing, Internet of Thing (IoT), and Artificial Intelligence (AI) (Yadika in Disemadi \& Kang 2021). Meanwhile, Indayani and Hartono (2020) revealed that social restrictions during the pandemic have hampered economic activity; both the production and distribution process by the company as well as the consumption process by the public so that many employees experienced layoffs in order to maintain the company's internal financial stability. 
Moreover, the digitalization process in almost all sectors including education has accelerated due to the Covid-19 pandemic (Maksum \& Fitria 2021). Various kinds of activities including teaching and learning activities must be taken online. This is due to an appeal to avoid crowds to prevent the spread of Covid-19. Therefore, all physical activities in the real world as much as possible should be converted into digital activities in cyberspace. In short, teaching and learning activities are currently changing from offline to online by utilizing available digital media.

Apart from digitization, the pandemic, the projection of the demographic bonus can also be a factor in the emergence of mass unemployment in the future, especially for Indonesia. The demographic bonus allows Indonesia to have a large number of workers of productive age. In 2030-2040, Indonesia's productive age is predicted to be around $64 \%$ of the total population (Bappenas 2017). In addition, the results of the population census of Indonesia in 2020 show that the $\mathrm{Z}$ generation, born in 1997-2012, is the population group with the highest percentage of $27.94 \%$ compared to residents of other age groups (Badan Pusat Statistik 2021). It means that in the next few years, Indonesia will have an abundance of workers. One thing to note is that the demographic bonus can be a disaster that causes mass unemployment when the workforce, dominated by the younger generation, cannot face the new world after the emergence of the digital era and pandemics.

The emergence of digitalization, pandemics, and demographic bonuses that can result in unemployment due to reduced employment opportunities, as described above, makes it essential to improve the quality of education. It aims to produce competent graduates with adequate levels of knowledge and skills. Such knowledge and skills can be used as capital to get decent work, so that unemployment and poverty can be suppressed and the country's economic growth can be maintained. It is in line with Pahlawan and Ratna (2018), who said that education, unemployment, poverty, and even economic growth have close relationships and influence each other.

Concerning the problems above, one educational institution that needs to improve its quality seriously is the vocational high school. Gumelar et al. (2020) declared that the purpose of establishing vocational high schools in Indonesia is to produce graduates who are ready to work with particular skills. Ironically, vocational high school graduates occupied the highest open unemployment rate until February 2020, with a percentage of $8.49 \%$ (Badan Pusat Statistik 2020). Worse than that, the open unemployment rate from vocational school graduates increased to $13.55 \%$ in August 2020 or after being affected by the pandemic (Wicaksono 2021). Therefore, the revitalization of vocational high school graduates is a must so that the unemployment rate can be suppressed, especially for those already designed to be a ready-to-work generation.

In order to overcome the problems above, the government launched a link and match policy to create relevance between the competence of vocational graduates and the needs of workers in the industrial world (Aminudin 2020). The implementation of this policy includes strengthening cooperation between industry and vocational high schools and the procurement of new study programs following industry needs. Unfortunately, creating relevance between the competencies of vocational high school graduates and the criteria for workers in the industrial labor market has factually not been able to reduce the high open unemployment rate among this kind of school graduates.

Departing from the problems above, the author concludes that the link and match policy alone is not enough if the students themselves do not master the competencies being taught because they experience demotivation in learning, especially during a pandemic like nowadays. Virtually distance learning which has been going on for more or less a year, has more or less made the students feel bored (Gandhawangi 2021). The research conducted by Rinawati and Darisman (2020) also concluded the same thing; studying at home leads to 
boredom. The author believes that boredom can be overcome by carrying out a creative, innovative, and varied learning process. Therefore, teachers play an essential role in achieving this. The learning model applied by the teacher must, of course, be developed to overcome these problems.

The first step that can take to prepare competent vocational high school graduates in the digital era is by applying to learn oriented to mastering the three new literacy skills. Lase (2019) argued that data, technological, and human literacy must be master to adapt to the digital era of dynamic changes and intense competition. Those who are adaptive are more

likely to be able to find work. Even though many jobs are replaced by technology, new jobs will still emerge (Siregar, Sahirah \& Harahap 2020). Mastery of these three new literacy skills will be one of the keys to getting the latest type of work in the digital era (Ibda \& Rahmadi 2018).

\section{METHODOLOGY}

This research uses a descriptive approach as a part of the qualitative method by adopting the content analysis technique to collect data. Some sources: journal articles, reports, and news, which were related to the discussion about learning models, had been chosen by the author. The data collecting technique, which is adopting content analysis, could provide relevant issues comprehensively (Babbie in Zainol, Majid \& Saad 2018). Through the literature collected, the author will then describe what learning models are suitable to be applied to improve the new skills that need to be mastered by vocational high school graduates in the future.

\section{RESULTS AND DISCUSSION}

\section{Research-based Learning to Enhance Data Literacy}

Research-based learning can be done as an initial step to foster a culture of data literacy. This is because this learning provides an opportunity for someone to seek information, formulate hypotheses, collect data, analyze data, and make conclusions on the data that has been compiled (Fitriyani \& Aziz 2019). By conducting research-based learning, it is hoped that future vocational graduates will be accustomed to reading, analyzing, and using data obtained from the digital world thanks to data literacy skills that are sharper than before. Furthermore, Slameto (2020) revealed that research-based learning is effective for increasing students' understanding of new knowledge. In addition, the learning process that emphasizes the problem-solving process can trigger students' curiosity and can avoid boredom compared to only receiving material and doing conventionally repetitive tasks. The research learning model can be carried out in certain subjects in each semester.

Strengthening data literacy of vocational high school graduates' students through research-based learning models can be carried out gradually. Wardani (2016) said that research-based learning simplification is to go through 3 stages: preparation, implementation, and evaluation. The preparation stage contains the provision of basic material on how to conduct research. Furthermore, the implementation phase will begin with the formation of groups and their research topics, execution of research activities, preparation of research reports in a scientific paper, and presentation of research results followed by question-andanswer activities with teachers and students from other groups. Evaluation in the form of 
providing feedback from the teacher becomes the final stage after all groups have completed the implementation stage.

\section{Interactive Multimedia-based Learning for Increasing Technological Literacy}

Furthermore, the technological literacy level of vocational high school graduates' students can be increased through interactive multimedia-based learning. Melianti, Risdianto and Swistoro (2020) assessed that the learning process by displaying audio-visual shows such as animations was able to attract students' interest in learning. The use of various kinds of current applications regarding design and other visual forms needs to be applied in learning. It aims to stimulate the imagination of vocational students so that they can think creatively. In addition, their understanding of the workings of technological innovation can also be improved with a learning model that uses the animated display. This kind of learning method is expected to attract students' interest to continuously improve their knowledge and skills in order to develop technological literacy. This interactive multimedia-based learning places the teacher as the center. The media used in delivering certain material in each semester is expected to be adapted to the implementation of the learning model that prioritizes the use of audio-visual media such as animation and others.

\section{Project-based Learning to Empower Human Literacy}

The last, in an increasingly complex world of work, human literacy skills are needed so that humans can function properly in their environment. The ability to interact, cooperate, and adapt are some examples of the "soft skills" needed in the digital era to make a person have a good capacity as a social being (Habiby et al. 2018). This ability is known as human literacy. In short, the author has the view that project-based learning is an effective way for students to hone the skills mentioned earlier.

The project-based learning model prioritizes the process of creating learning outcomes that are carried out in teams by relying on creative thinking (Rati, Kusmaryatni \& Rediani 2017). Students can be freed to create a product either physically, prototype, or digitally applicable design related to the study program they take. The knowledge and skills honed so far can be tested through a project-based learning model. The most important thing in this learning is the emphasis on teamwork related to the process of interaction, communication, and others as an element of soft skills which is a representation of human literacy. The results of each team's project will later be displayed in an exhibition which is participated by all teams from each class in the school before the promotion test.

\section{CONCLUSION}

In conclusion, the three learning models proposed by the authors above aim to increase the three new literacy skills for vocational high school graduates in a creative way to avoid student saturation which can result in failure to understand the material. Research-based learning is applied to hone data literacy, while technological literacy and human literacy are honed through interactive multimedia-based learning and project-based learning. It is hoped that vocational high school students' understanding of the material presented using these three learning models can be improved so that the three new literacies needed in the digital era to compete in the world of work also increase. That way, the threat of mass unemployment in the future caused by a technological disruption in the digital era, which is accelerating with the emergence of the Covid-19 pandemic, as well as the projection of the demographic bonus, 
which can also be an additional factor, hopefully, can be overcome if vocational high school graduates who are programmed to directly ready to work have the three new literacies as the main capital in taking part in the world of work in the digital era.

\section{ACKNOWLEDGEMENTS}

This work was supported by the Faculty of Social and Political Sciences as well as the Department of Sociology in Universitas Gadjah Mada.

\section{REFERENCES}

Aminudin, Muhammad. 2020. "Link and Match Pendidikan Vokasi \& Dunia Kerja, Kemendikbud Gaet Industri." DetikNews. 2020. https://news.detik.com/berita/d5208363/link-and-match-pendidikan-vokasi--dunia-kerja-kemendikbud-gaet-industri.

Badan Pusat Statistik. 2020. "Keadaan Ketenagakerjaan Indonesia Februari 2020.” Badan Ketenagakerjaan Indonesia.

Badan Pusat Statistik Provinsi Papua. 2021. "Hasil Sensus Penduduk 2020.". https://papua.bps.go.id/pressrelease/2018/05/07/336/indeks-pembangunan-manusiaprovinsi-papua-tahun-2017.html.

Bappenas. 2017. "Bonus Demografi 2030-2040: Strategi Indonesia Terkait Ketenagakerjaan Dan Pendidikan.” Jakarta.

Disemadi, Hari Sutra, and Cindy Kang. 2021. "Tantangan Penegakan Hukum Hak Kekayaan Intelektual Dalam Pengembangan Ekonomi Kreatif Di Era Revolusi Industri 4.0.” Jurnal Komunikasi Hukum 7 (1): 54-71.

Fitriyani, Yani, and Ikhsan Abdul Aziz. 2019. "Literasi Era Revolusi Industri 4.0.” In Seminar Nasional Bahasa Dan Sastra, 1:100-104.

Gandhawangi, Sekar. 2021. "Pembelajaran Jarak Jauh Bikin Siswa Jenuh, Guru Dituntut Variatif." Kompas. 2021. https://www.kompas.id/baca/dikbud/2021/03/04/pembelajaran-jarak-jauh-bikinsiswa-jenuh-guru-dituntut-variatif/.

Gumelar, Bagus, Ahmad Rizal Solihudin, Fatwa Tentama, Siti Kurnia Widi Hastuti, Surahma Asti Mulasari, Sulistyawati, Tri Wahyuni Sukesi, and Rokhmayanti. 2020. "TOT Kesiapan Kerja Dan Pendidikan Anti Korupsi Dan Narkoba Bagi Siswa Di Sekolah Menengah Kejuruan (SMK)." In Seminar Nasional Hasil Pengabdian Kepada Masyarakay, 137-46.

Habiby, Wahdan Najib, Aulia Maulida Rahmah, Nabila Alfiarini Mutiara Primasti, and Pipit Indah Pranoga. 2018. "Peran Mahasiswa Sebagai Penghubung Antar Era Melalui Pembuatan Media Pembelajaran Bagi Guru Di Pedesaan." In Seminar Nasional Pendidikan 2018 "Mengembangkan Kompetensi Pendidik Dalam Menghadapi Era Disrupsi" - Kerjasama PGSD POR UMS, 295-306.

Ibda, Hamidulloh, and Erdom Rahmadi. 2018. "Penguatan Literasi Baru Pada Guru Madrasah Ibtidaiyah Dalam Menjawab Tantangan Era Revolusi Industri 4.0.” JRTIE: Journal of Research and Thought of Islamic Education 1 (1): 1-21.

Indayani, Siti, and Budi Hartono. 2020. "Analisis Pengangguran Dan Pertumbuhan Ekonomi Sebagai Akibat Pandemi Covid-19." Perspektif: Jurnal Ekonomi \& Manajemen Universitas Bina Sarana Informatika 18 (2): 201-8.

Lase, Delipiter. 2019. "Pendidikan Di Era Revolusi Industri 4.0." Jurnal Sundermann 1 (1): $28-43$. 
Maksum, Ali, and Happy Fitria. 2021. "Transformasi Dan Digitalisasi Pendidikan Di Masa Pandemi." In Prosiding Seminar Nasional Pendidikan Program Pascasarjana Universitas PGRI Palembang, 121-27.

Melianti, Erina, Eko Risdianto, and Eko Swistoro. 2020. "Pengembangan Media Pembelajaran Berbasis Multimedia Interaktif Menggunakan Macromedia Director Pada Materi Usaha Dan Energi Kelas X.” Jurnal Kumparan Fisika 3 (1): 1-10.

Pahlawan, Putri Yaumul, and Ratna. 2018. "The Effect of Education Level, Unemployment Rate and Economic Growth on Poverty Rate in Indonesia 2012-2017 Period.” Journal of Maliksussaleh Public Economics 1 (2): 44-49.

Rati, Ni Wayan, Nyoman Kusmaryatni, and Nyoman Rediani. 2017. "Model Pembelajaran Berbasis Proyek, Kreativitas Dan Hasil Belajar Mahasiswa.” JPI : Jurnal Pendidikan Indonesia 6 (1): 60-71.

Rinawati, Desy, and Eka Kurnia Darisman. 2020. "Survei Tingkat Kejenuhan Siswa SMK Belajar Di Rumah Pada Mata Pelajaran Produk Kreatif Dan Kewirausahaan Selama Masa Pandemi Covid-19." Journal of Science and Education (JSE) 1 (1): 32-40.

Siregar, Nurhayani, Rafidatun Sahirah, and Arsikal Amsal Harahap. 2020. "Konsep Kampus Merdeka Belajar Di Era Revolusi Industri 4.0.” Fitrah: Journal of Islamic Education 1 (1): 141-57.

Slameto, Slameto. 2020. "Peningkatan Hasil Belajar Melalui Pembelajaran Berbasis Riset." Jurnal Ilmiah Pendidikan TRISALA 1 (16): 131-44.

Wardani, Naniek Sulistya. 2016. "Pengembangan Model Pembelajaran Berbasis Riset Untuk Meningkatkan Keterampilan Berpikir Aras Tinggi.” In Prosiding Konser Karya Ilmiah Nasional, 2:213-28.

Wicaksono, Adhi. 2021. "Menaker Ungkap Sebab Lulusan SMK Dominasi Pengangguran Di RI." CNN Indonesia. 2021. https://www.cnnindonesia.com/ekonomi/20201211140123-92-580934/menakerungkap-sebab-lulusan-smk-dominasi-pengangguran-di-ri.

Zainol, Nur Zainatul Nadra, Latifah Abdul Majid, and Mohd Faizulamri Md Saad. 2018. "An Overview on Hermeneutics Method Application to the Quran by Muslim Thinkers." International Journal of Engineering and Technology 7 (3.25): 681-84.

ISMADA FIRDAUS MANDALA PUTRA

Universitas Gadjah Mada

Bulaksumur St., Caturtunggal 55281

Yogyakarta, Indonesia

*Corresponding author: ismadafirdausmp@mail.ugm.ac.id

Received: 31 August 2021 / Accepted: 2 November 2021 / Published: 20 November 2021 